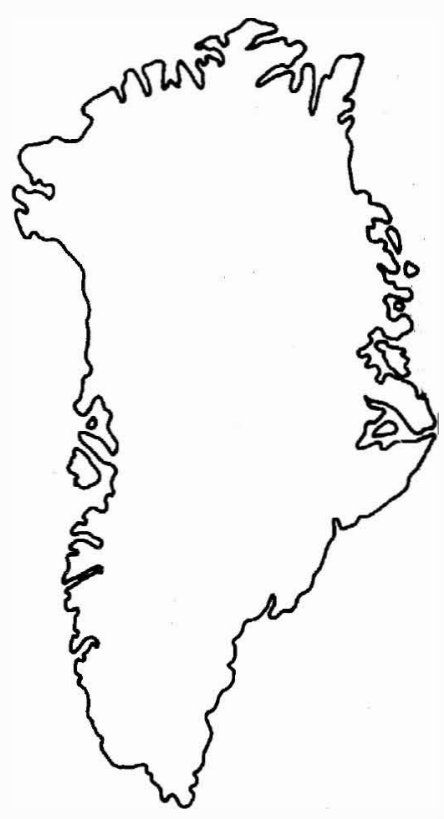

\title{
Silurian trilobites from the G. B. Schley Fjord region, eastern Peary Land, North Greenland
}

\author{
Alan T. Thomas
}

\begin{abstract}
A trilobite fauna of Pterospathodus celloni Biozone age (late Llandovery) is described from a horizon near the top of the Odins Fjord Formation. The commonest trilobite is the phacopid Acernaspis sp., with which are associated the proetid Cyphoproetus? cf. C. alyo, the harpetid Scotoharpes?, a second phacopid (Ananaspis?), the encrinurid Briania and an undetermined encrinurid. The trilobite species compare closely with others already described from various localities in the mid-late Llandovery of Greenland and Canada. The overall composition of the trilobite fauna, however, contrasts with that previously known from the Odins Fjord Formation; this may partly reflect the more offshore position of the Schley Fjord fauna on the Peary Land shelf. However, drowning of the shelf produced a possibly diachronous decrease in faunal content and diversity as deepening and muddying progressed southwards over time. Thus, faunal contrasts may simply reflect sampling of different levels within this muddying-upwards succession.
\end{abstract}

A. T., School of Earth Sciences, University of Birmingham, Edgbaston, Birmingham B15 2TT, UK.

The small collection of trilobites described here was obtained by R. L. Christie and J. R. Ineson in 1978 when they were engaged in the reconnaissance field mapping programme of the Peary Land region. These fossils are the most northerly Silurian trilobites discovered. The section from which the trilobites (GGU 197562; Fig. 1) were collected spans the boundary between the carbonates of the Odins Fjord Formation (of Hurst, 1984; the former un-named Silurian Limestone Formation of Christie \& Peel, 1977), and the overlying shaly mudstones (Thors Fjord Member) and sandstone turbidites of the Wulff Land Formation (Christie \& Ineson 1979, p. 69). The upper $30-40 \mathrm{~m}$ of the Odins Fjord Formation limestones at this locality show a progressive facies change upwards, becoming darker, more argillaceous, thinly bedded and nodular. The fossils were collected from the uppermost beds of the Odins Fjord Formation, some 2-3 $\mathrm{m}$ below the top. The rock type is a thinly bedded, sparsely fossiliferous, silty wackestone which is grey to dark grey on fresh surfaces and weathers brown. In thin section the limestone is seen to be bioturbated, and stylolitic surfaces occur.

In the early Silurian, Peary Land lay near to the eastern exposed end of a large carbonate platform, which extended some $800 \mathrm{~km} \mathrm{E-W}$, and $100 \mathrm{~km} \mathrm{N-S}$ (Surlyk \& Ineson, 1992; Higgins et al., 1991; Sønderholm \& Har- land, 1989; Sønderholm et al., 1987). The northern boundary of the platform was marked by the Navarana Fjord Lineament. As the platform foundered in the late Llandovery, the active carbonate margin back-stepped to the south (Surlyk \& Ineson, 1992, p. 401). Hurst (1984, p. 44) interpreted the upper part of the Odins Fjord Formation in this region to have been deposited under low energy conditions, possibly below the photic zone. If this interpretation is correct, the trilobites are unlikely to have suffered significant transport. A depositional environment situated at the transition from the mid to outer shelf may be suggested by the association of conodont genera which occurs (see below; Armstrong 1990, fig. 26, p. 36).

Silurian trilobites from northern Greenland have become much better known over the last twenty years (Lane, 1972, 1979, 1984, 1988; Lane \& Owens, 1982; Lane \& Siveter, 1991), though much material remains to be described. The Odins Fjord Formation fauna dealt with by Lane (1988) is also from the celloni Biozone, and therefore is at least approximately coeval with that described here. Lane's fauna, which was collected about $100 \mathrm{~km} \mathrm{SW}$ of GGU 197562, contains the styginid Opoa, the encrinurids Perryus (=Enrinuroides palasso Lane; see Edgecombe \& Chatterton 1992, p. 68) and Distyrax, the pterygometopid Podowrinella and the odontopleurid 


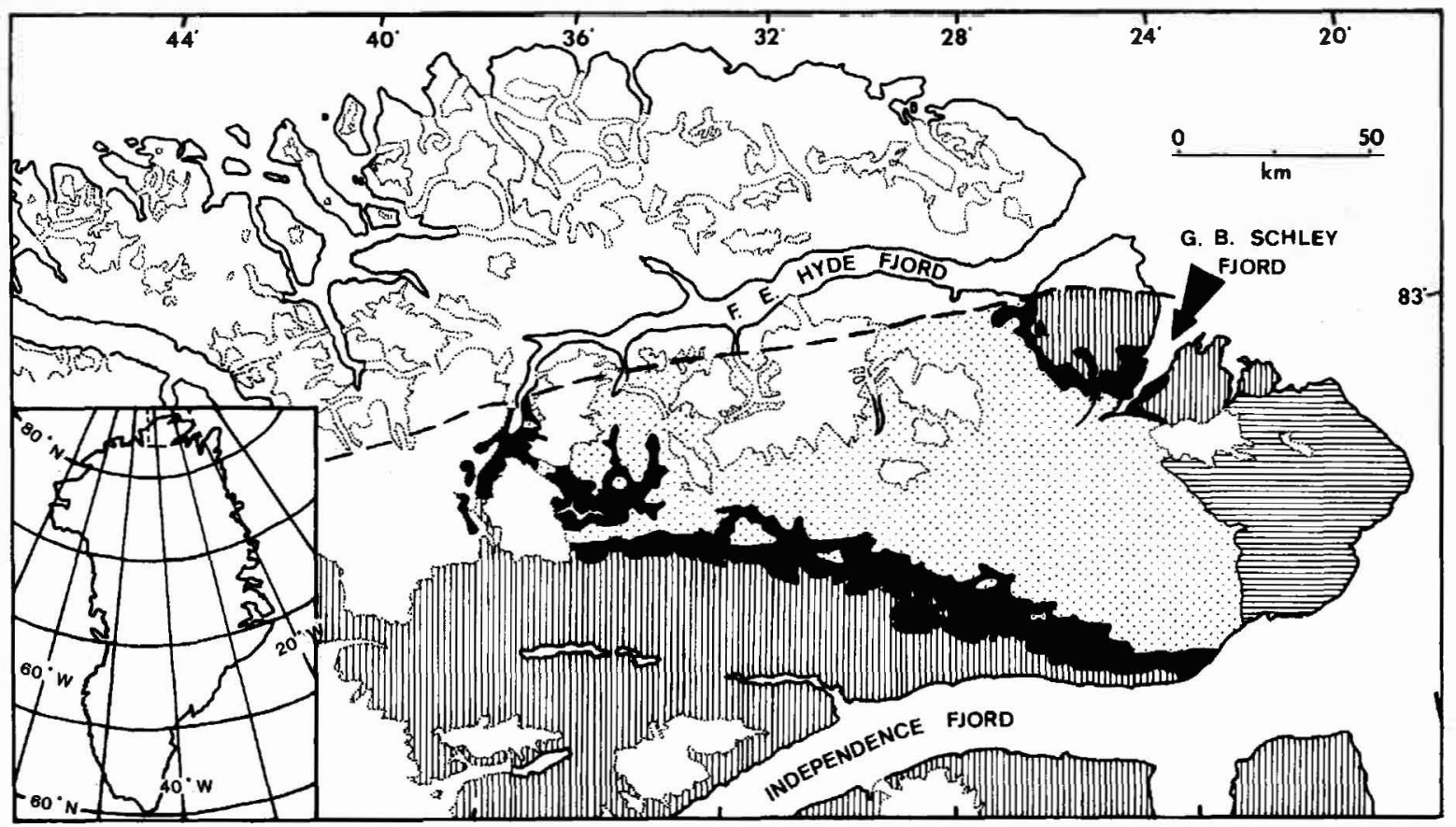

Fig. 1. Peary Land region, showing the geographical position of GGU 197562 (marked with a small arrow). Dashed line running E-W to the south of Frederick E. Hyde Fjord marks the early Silurian shelf edge (Navarana Fjord Lineament). Silurian carbonate formations are shown in black. Vertical shading marks the underlying Proterozoic to Ordovician units; stippling indicates younger Silurian rocks. Wandel Sea Basin (Upper Carboniferous to Lower Tertiary) is shaded horizontally. The Inland Ice is marked by finely broken lines. Inset map of Greenland shows area of enlarged map.

Gaotania. Associated with these are abundant brachiopods, pelmatozoan debris and (mainly smooth) ostracodes, with some gastropods, bivalves, and rugose and tabulate corals. The aspect of the fauna as a whole, and the trilobite component in particular, is thus rather different from that described here. Such contrasts in the composition of coeval Silurian trilobite associations are known elsewhere (Thomas, 1980, p. 450; Thomas et al., 1984 , p. 50). In this case they could reflect the more offshore position of GGU 197562 on the Peary Land shelf (Hurst, 1984, fig. 66D, p. 63; fig. 70, p. 67). However, the fossils were collected only $2-3 \mathrm{~m}$ below the the top of the Odins Fjord Formation, in a transitional, nodular, argillaceous wackestone lithofacies. This lithofacies reflects the gradual deepening and muddying of the outer part of the Peary Land shelf which took place as foundering occurred. On a regional scale, this lithofacies is probably slightly diachronous, extending southwards with time. The trilobite fauna described by Lane (1988) from the Odins Fjord Formation was collected about $20 \mathrm{~m}$ below the top: that fauna was therefore from a different level in the sequence, which deepens and becomes more argillaceous upwards. This palaeoenvironmental contrast may provide a sufficient explanation of the differences in composition between the two faunas.

\section{Composition, preservation and age of the fauna}

R. L. Christie and J. R. Ineson were primarily engaged in field mapping when they collected this fauna, and the size of the sample is therefore small (47 macrofossils, excluding brachiopods). Disassociated trilobites are the commonest macrofossils (31 specimens), next most common are orthoconic and cyrtoconic cephalopods (13 specimens) and articulate brachiopods (currently being studied by M. G. Bassett), with two high-spired gastropods (Loxonema? sp.) and a single thlipsuracean? ostracode. The limestone which encloses the fossils is highly indurated and adheres to the trilobites with great tenacity: generally the exoskeleton clings to the external mould. Preparing the fossils from the matrix is consequently exceedingly difficult. Some of the phacopid cranidia were therefore only partly prepared, in order to avoid causing an unacceptable level of damage to the specimens.

Surplus limestone was trimmed from the blocks which contained macrofossils. In this way, approximately $2.4 \mathrm{~kg}$ of rock was separated and kindly processed for conodonts by R. J. Aldridge. The sample yielded a rich fauna of conodonts (1767 elements) and acrocretacean brachio- 
nods. Some of Aldridge's identificalions are provisional. but the biostratigraphicully important species are unequivocal. Pseudolonchodina fucyeli dominates the assemblage (1374 clements). The celloni Biozone age is indicated by the presence of the nominate species 139 elements), and the occurrence of Astropensagnathus irregularis (97 etements) is indiculive of the lower part of that biozonte. Associated with these are (element numbers given in brackets): Panderodus spp. (117), Carniodus (25). Ozarkadina spp. (20), Decoriconus fragilis (10), Dentacodina? (6), Belodella (5) and Pseiudomeorodus (1).

\section{Systematic palaeontology}

\section{Family Proetidae Salter, 1864 Subfamily Proetinae Salter, 1864 Genus Cyphoproetus Kegel, 1928}

Type species. Cyph. depressa Barrande, 1846, p. 60, from the Liteñ Formation (Wenlock) of Lištice, Prague district, Czechoslovakia.

\section{Cyphoprochus? cf. C. alyo Lane, 1979 Fig. $2 \mathrm{H}$}

Material, MGUH 22161 from GGU 197562, GGU 197562.1, free cheeks.

Discussion. This specimen compares very closely with the specinen figured by Lane (1979, pl. 3, fig. 7) and agrees in all respects wilh his description (1979, p. 21). In view of the fragmentary miture of the present specimen, the identification is inevitably equivocal, $C$ ? chlye was originally described from rocks of Coronograptus gregarius Biozone age (lower Aer(mizun).

\section{Fanily Harpetidae Hawle \& Corda, 1847 Genus Scotoharpes Lamont, 1948}

Type species. Scotoharpes domina Lamont 1948, p. 535, pl. I, fig. 2, from the upper Llandovery of the North Esk Inlier, Scotlind.
Scotoharpes? sp.

Figs 2A, G

Material. MGUH 22162a, b Irom GGU 197562, hrim fragment and cotsmterpar.

Discussion. This fragment is provisionally assigned to Scotoharpes, a widespread genus common in the Llandovery of northem Greenland, on account of its overall similarity to specimens such as that figured by Lane (1979, pl. 5, fig. 3). In the absence of the axial part of the cephalon, however, the identification is provisional. One character which distinguishes species of Scotoharpes is the number of small pits in the width of the brim. These pits are difficult to count properly in the present specimen for preservational reasons: there seem to be about 24 . In S. loma, from the upper Llandovery or Wenlock of Kmnprins Christian Land, this number is about 40 (Lane 1972. p. 353). Scotoharpes sp. of Lane (1979, p. 24), from the Llandovery (Idwian, now lower Aeronian, BI, or slightly older) of Washington Land, has 20-22 pits.

Family Phacopidae Hawle \& Corda, 1847

Subfamily Phacopinae Hawle \& Corda. 1847

Genus Acernaspis Campbell, 1967

Type species. Phacops orestes Billings, 1860, from the Jupiter and Gun River formations (Llandovery), of Anticosti lsland, Camada.

\section{Acernaspis sp.}

Figs 3A-J

Material. MGUH 22163-6 from GGU 197562.2-9, cralnidia; MGUH 22167 from GGU 197562. 10, tree cheeks; MGUI1 22168, thoracic segment: MGUH 22169-70 from GGU 197562.11, 12, pygidia: all MGUH specimens from GGU 197562. One poorly preserved pygidim (GGU 197562,13) may also betong to this species.

Discussion. In cephalic morphology, this species compares closely with the type species (Camphell, 1967, pl. 12 figs I-3; pl. 13, fig. 8). Comparison is linited, however, hecause the present species is known naainly from internal moulds. Pygidia of Acernaspis sp. differ from these of $A$. oresses in being wider and shorter. Acernaspis species are typical of the Llandovery, hut the genus ranges up into the Wenlock. 

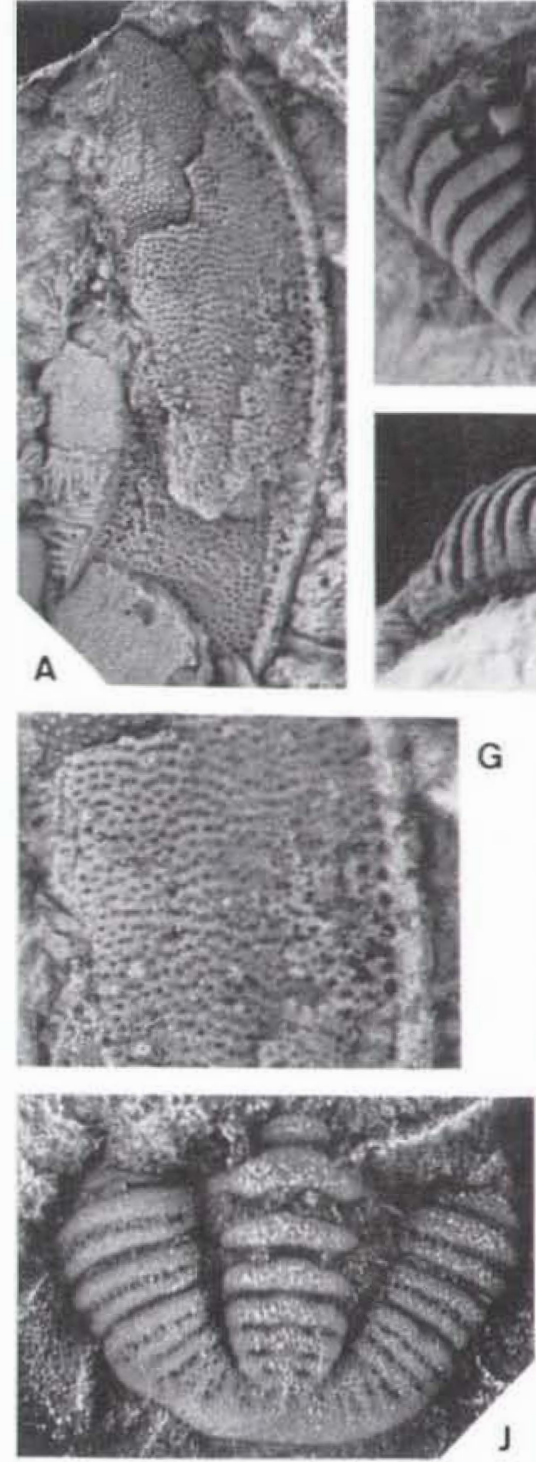
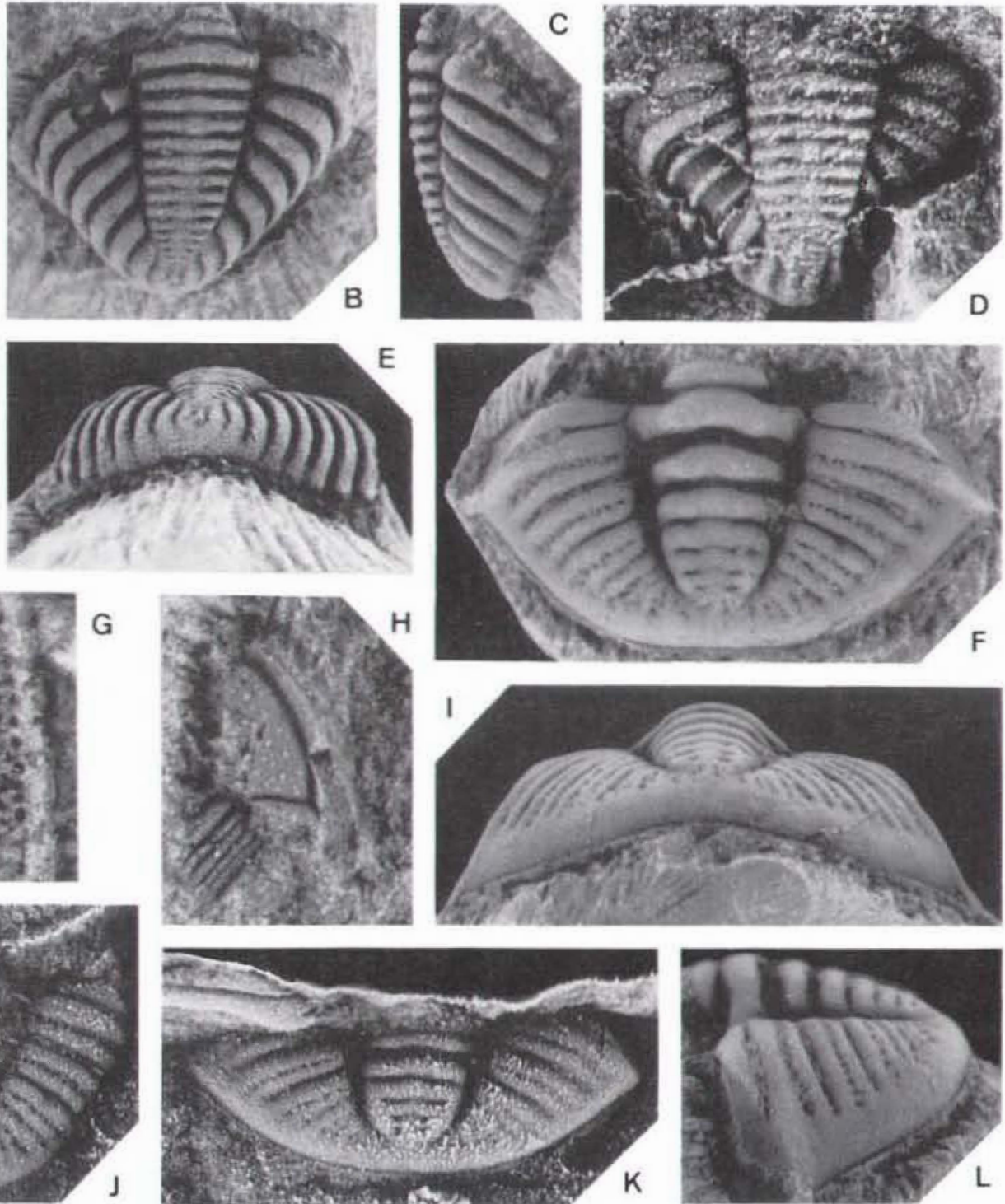

Fig. 2. A. G Seotoharpes? sp. MGUH 22162, latex tast from cesunterpast of brim fraginent, dorsal view. $\times 2.5$ and $\times 5.5$, C, E. Briania sp., MGUH 22174, pygidlsm, dorsal, lateral and pesterior views, $\times$ |0. D, MGUH 22175, encrinurine gen. and sp. indet. latex cast from exitrnal mould of pygidium, dorsil view, x 10, F. I. J-L. Anomatis? sp, F, I, I., MGUH 22171. pygidium, dorsal. posicrior and lateral views, $\times 8$, J, MGUH 22172, latex cast from counterpall of pygidium, dorsal view, $\times 6, \mathrm{~K}, \mathrm{MGLH} 22173$, latex

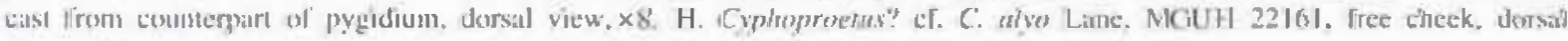
view, $\times 10$

Gellus Ananaspis Campbell, 1967

Type species. Phacops fecomdus Barrande, 1846, p. 46. from the Kopanina Formation (Ludlow). Kolednik, near Beroun, Crechoslovakia.
Ananaspis? sp.

Figs 2F, 1-1.

Material. MGUH 22171-3 from GGU 197562, pygidia.

Description. Pygidium almost twice as wide as long. with distinct border. Axis slightly more than one third maximum pygidial width anteriorly, Five complete axial rings. but fourth and lifth defined posieriorly by furrows which are very shallow sagittatly; sixth axial ring detined only 
by apodemal pits. Pleural area with six pleural furrows: anterior four of these distinct, posterior two consist of aligned pits. Six interpleural furrows, all consisting of aligned pits. Anteriou and posterior pleural bands of similar length (exsag.).

Discussiom. This species is known only from internal surfaces: in the two specimens preserved as counterparts. the recrysiallized exoskeleton is visible as a slightly paler layer which grades into the limestone matrix. On first inspection, one specimen (Fig. 2J) appears to the transiIny pygidium. However, the deep furrow which posteriorly bounds the anterior two "segments" is a pleural, not an interpleural, furrou:

The specimens are questionubiy assigned to Ananaspis on the basis of the well-developed segmentation (Chlupác, 1977. p. 77). Anañaspis? sp. has fewer axial rings and pairs of pleural ribs than species unequivocally assigned to that genus, but it is stratigraphically older than any of them. Pygidia of Acemaspis are much less strongly segmented. The pitted nature of the interpleural furnow is matched in a number of Ananaspis species (Chlupac, 1977. pl. 4, figs 12-15; pl. 5, figs 23) and in some other phacopids.

Family Encrinuridae Angelin, 1854

Subfamily Encrinurinae Angelin, 1854

Genus Briania Edgecombe, 1994

Type species. Briania jefferroni Edgecombe 1994, p. 827. figs 2.1-2.16, 3.1-3.4? 3.5-3.22, from upper Telychian part of Whittaker Formation, east of Avalanche Lake. Districa of Mackenzic, Canada.

\section{Briania sp.}

Figs 2B, C, E

Material. MGUH 22174 from GGU 197526, pygidium.

Discission. This specimen shows general similarities to a number of stratigraphically younger encrinurines such as Fragiscutum glebale (Campbell, 1967, pl. 8. Figs 3, 9, 18) and Simszia obmsa (see Ramsköld, 1986, pl. 48, figs 2c, 7-10). It is closest, however, to the monotypic Briania Edgecombe (1994, tigs 3.8-3.22). Similarities include the pygidial length:widith proportions, the anterior width of the axis relative to tolal pygidial width, axial shape and pattem of segmentation, the very shallow sagittaj band with subdued tubercles, and the pleural inter-ib furrow and rib morphology. Anteriorly the latter teminate in blunt, subquadrate lips, whercas posteriorly the inter wib furnows are almost effaced distally (Figs 2C, E), though this is not a cluaracier unique io Brimia (e.g. sec Thomas \& Narbonne, 1979, pl. 3, lig. 6). The present specinsen ditfers from B. jeffersoni is having 15 (not 16-19) distinct axial rings, only 8 (not $10-11$ pleural ribs) and a slightly lower R/P (Ramisköld, 1986, p. 529) ratio (1.66 rather than 1.78). Thew differmees are unlikely w he of more than specific significauce. Many of the diagnostic characters of Briania are cephalic, however, so a full comparison with the type species is not possible.

Brionia jeffersoni was described front late Telychian sirata (Prerospahodus amorphognatwerides Biozone; though graptolite/trilohile correlations suggest a slightly older age, Edgecombe, 140)4. p. 824), rocks a little younger than those dealt with here. Nevertheless, the new record reinforees the general hiostratigraphical utility of some Silurian encrinurid taxa which has been noted previousty (Edgecombu. 1994, p. 826: Thomals ef al. 1984, p. 51 ).

Encrinurine gen. and sp. indet.

Fig. 20

Material. MGUH 22175 from GGU 197562, extemal mould of incomplete pygictiun.

Discussion. This specimen clearly represents a different taxon from Briania sp., differing most obviously in the wide axis and shorter (exsag.) pleural ribs which are separated by much broader inter-rib furrows. It camnos be assigned to any of the seven named encrinurine genera recorded from Telychiun rocks by Edgeconthe (1994. fig. 1. p. 825), and instead probably belongs to what he described as the group of variolaris-plexus plesionompins. Except for the less rapidly tapering axis, the present specimen is similar in most respocts w a pygidium from the late Landovery of the North Yukon described by Ludvigsen \& Tripp (1990, p. 24, pl. 9, fig. 6) as Encrin. uraspis sp. G. D). Edgecombe (personal commutrication, November 1993) informs me that is related species from the amorphograthoides Biozone in the Mackenzie Mountains indicates placement in the variolaris-plexus. related to Balizmma, Struszia, and other post-Llandovery genera.

The only other encrimurid specimen found in the sample is a small librigenal? fragment (GGU 197562.14). Given its fragnentary nature, it cannot be further identified.

Acknowledgemients. I thank Drs G. 1). Figecombe, P. D. Lane and M. P. Smith for their helpfull custruents an the mamescript. 

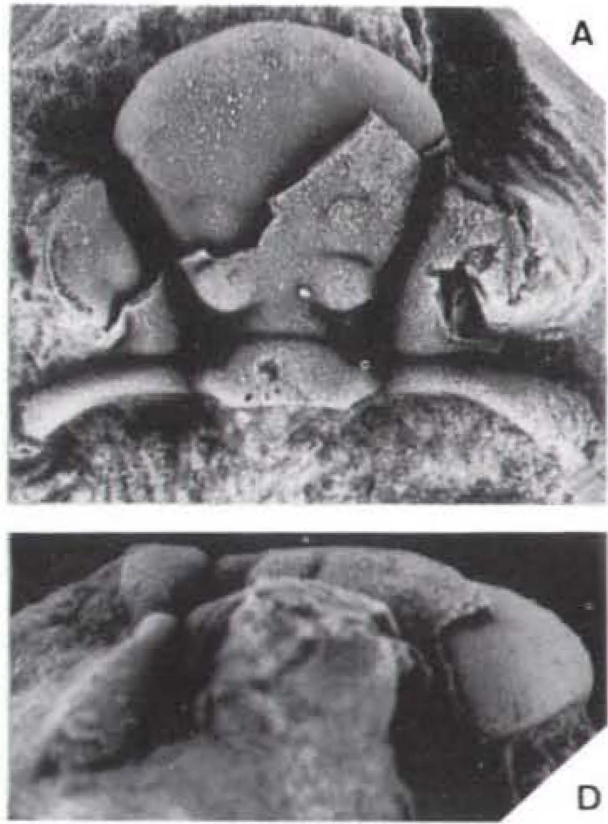
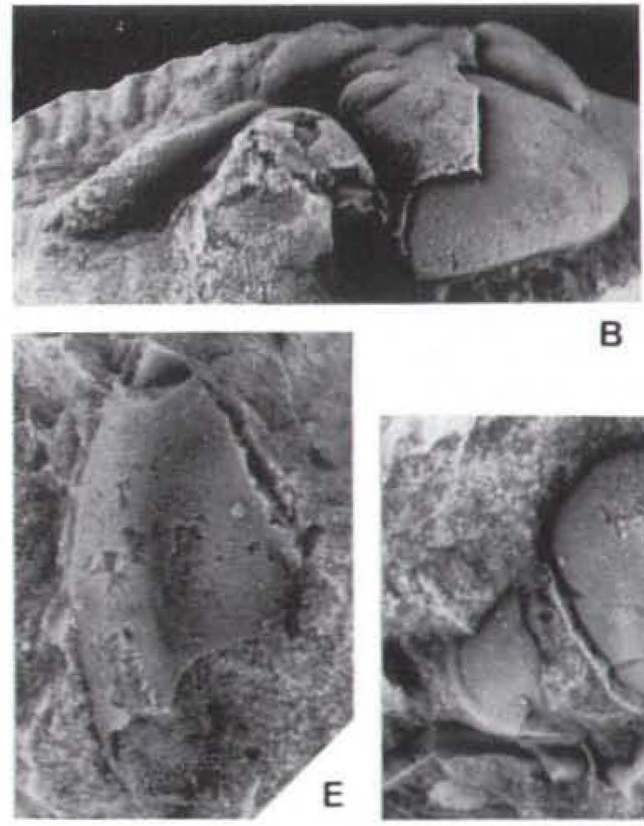

B

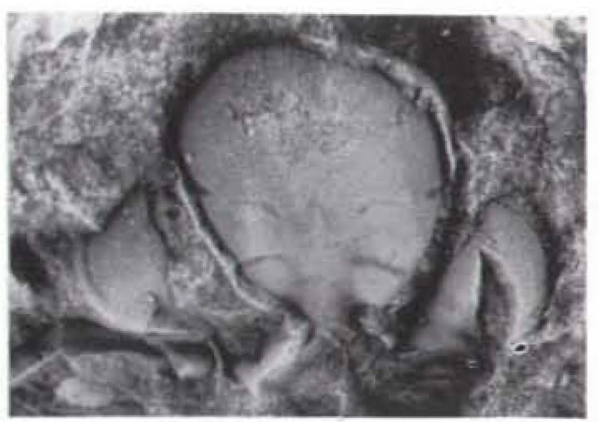

F

G

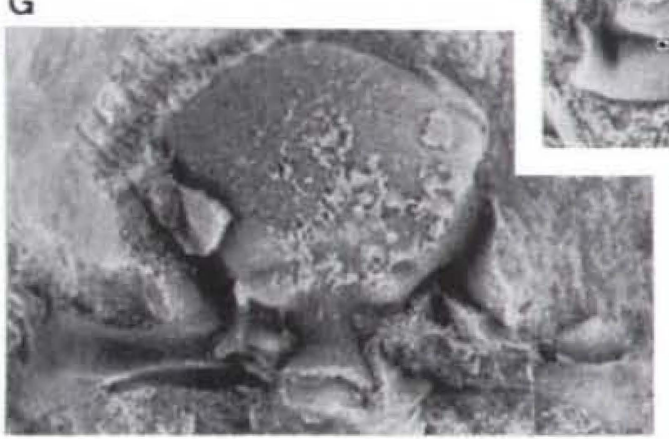

$\mathrm{H}$

J

Fig. 3. Aremaspis sp. A, B, D, MGUH 22163, partly exfoliated cranidium, palpebral and oblique anterolateral views, $x 8.1$ lateral view, $\times 10, \mathrm{C}$, MGUH 22164, latex cast from extemal mould of incomplete cranidium, $\times$ 7. E. MGU11 22167, free cheek. exierior view, $\times 6$. F, MGUH 22165. incemplete cranidium. palpebral view, $\times 5$. G. MGUH 22I60, internal mould of crasidium, dorsal view, $\times 5$. H, MGUH 22168, incomplete lhoracic segmem, dorsal view, x6. I, MGUH 2216\%, pygidium, dorsal view, x6. J, MGUH 22170 , largely exfrslinted pygidum. dorsil view, $\times 8$.

\section{Refierences}

Angelin. N. P. 1854: Palaennologia Scandinavica. 1. Crustacea formosionis iransiriomis 2, 21-9)2. pls 25-41. Lund.

Amstrong. H. A. 1990: Conodonts from the Upper Ordovician - Lower Silurian carbonale platform of North Greenland. Bull. Cironiands geed. Unders. 159. 151 pp., 23 pls.

Barrande, J. 1846: Notice préliminaire sur le Svstème Silurien et le's rrilobises de Hohêne. vĩ +97 pp.. Leipsic.

Billimgs. E. 1860: Descriptions of some new speries of fossils from the lower and middle Silurian rocks of Canada. Can. Notr. Geol. 5, 49-73, text-figs 1-12.

Camptell, K. S. W. 1967: Trilohites of the Henryhouse Formation (Silurian) in Oklahoma. Hull. ONa, geol. Sun: 115. $68 \mathrm{pp} .19 \mathrm{pls}$.

Chlupac, I, 1977: The phacopid Irilohites of the Silurian and
Devonian of Crecloslovilkia. Rozpr: Üst. Ust. seol, 4.3, 172 pl.. 32 pls.

Christie. R. L. \& Inesos, J, R. 1979: Precambrian-Silurian geology of the G. B. Schley Fijord region, eastern Peary Land. North Grecnland, Rapp. Gronlands geol. Unders. 88, 63-71.

Christie, R. L. \& Peel, J, S. 1977: Canbrian-Silurian stratigraphy of Burglum Eiv. Peary Land, eastern North Greenland. Rapp. Granlands geel. Uimders. 82. 48 pp.

Eugeconbe, G. D. 1994: New Lower Silurian (Llandovery) encrinurine trilobites from the Mackesicie Mountains, Canada. J. Paleont. 68, 824-837.

Edgeciombe, G. D. \& Chatterton, B. D. E. 1992: Early Silurian (Llandovery) encrinurine trilobites from the Mackenzie Moustains, Canada. J. Paleont. 66, 52-74.

Hawle, I. \& Corda, A. J. C. 1847: Prodrom einer Monographie 
der böhmischen Trilobiten, 176 pp., 7 pls. Prague (also 1848, Abh. K. böhm Ges. Wiss. 5, 117-292, pls 1-7).

Higgins, A. K., Ineson, J. R., Peel, J. S., Surlyk, F. \& Sønderholm, M. 1991: Lower Palacozoic Franklinian Basin of North Greenland. In Peel, J. S. \& Sønderholm, M. (ed) Sedimentary basins of North Greenland. Bull. Gronlands. geol. Unders. 160, $71-139$.

Hurst, J. M. 1984: Upper Ordovician and Silurian carbonate shelf stratigraphy, facies and evolution, eastern North Greenland. Bull. Grønlands geol. Unders. 148, 73 pp.

Kegel, W. 1928: Über obersilurische Trilobiten aus dem Harz und dem Rhenischen Schiefergebirge. Jb. preuss. geol. Landesanst. Berg Akad. 48 (for 1927), 616-647, pls 31, 32.

Lamont, A. 1948: Scottish dragons. Quarry Mgrs' J. 31, 531535, pl. 1.

Lane, P. D. 1972: New trilobites from the Silurian of north-east Greenland, with a note on trilobite faunas in pure limestones. Palaeontology 15, 336-364, pls 59-64.

Lane, P. D. 1979: Llandovery trilobites from Washington Land, North Greenland. Bull. Gronlands geol. Unders. 131, 37 pp., 6 pls.

Lane P. D. 1984: Silurian trilobites from Hall Land and Nyeboe Land, western North Greenland. Rapp. Grønlands geol. Unders. 121, 53-75, 4 pls.

Lane, P. D. 1988: Silurian trilobites from Peary Land, central North Greenland. Rapp. Grønlands geol. Unders. 137, 93$117,5 \mathrm{pls}$.

Lane, P. D. \& Owens, R. M. 1982: Silurian trilobites from Kap Schuchert, Washington Land, western North Greenland. Rapp. Gronlands geol. Unders. 108, 41-69, pls. 1-5.

Lane, P. D. \& Siveter, D. J. 1991: A Silurian trilobite fauna dominated by Calymene from Kap Tyson, Hall Land, western
North Greenland. Rapp. Grønlands. geol. Unders. 150, 5 114.

Ludvigsen, R. \& Tripp, R. P. 1990: Silurian trilobites from the Northern Yukon Territory. Royal Ontario Museum, Life Science Contributions 153, iv + 59 pp.

Ramsköld, L. 1986: Silurian encrinurid trilobites from Gotland and Dalarna, Sweden. Palaeontology 29, 527-575, pls. $37-49$.

Salter, J. W. 1864: A monograph of the British trilobites from the Cambrian, Silurian and Devonian formations. Palaeontogr. Soc. [Monogr.] (1), 1-80, pls 1-6.

Sønderholm, M. \& Harland, T. L. 1989: Franklinian reef belt, Silurian, North Greenland. In Geldsetzer, H. H. J., James, N. P. \& Tebbutt, G. E. (ed.) Reefs, Canada and adjacent area. Mem. Can. Soc: Petrol. Geol. 13, 356-366.

Sønderholm, M., Harland, T. L., Due, P. H. Jørgensen, L. N. \& Peel, J. S. 1987: Lithostratigraphy and depositional history of Upper Ordovician - Silurian shelf carbonates in central and western North Greenland. Rapp. Gronlands geol. Unders. 133, $27-40$.

Surlyk, F. \& Ineson, J. R. 1992: Carbonate gravity flow deposition along a platform margin scarp (Silurian, North Greenland). J. sedim. Petrol. 62, 400-410.

Thomas, A. T. 1980: Trilobite associations in the British Wenlock. In Harris, A. L., Holland, C. H. \& Leake, B. E. (ed.) The Caledonides of the British Isles - reviewed. Spec. Publ. geol. Soc. Lond. 8, 447-451, 1 pl.

Thomas, A. T. \& Narbonne, G. M. 1979: Silurian trilobites from arctic Canada. Geol. Mag. 116, 1-19, 5 pls.

Thomas, A. T., Owens, R. M. \& Rushton, A. W. A. 1984: Trilobites in British stratigraphy. Spec. Rep. geol. Soc. Lond. $16,78 \mathrm{pp}$. 